\title{
Thalamic deep brain stimulation in the treatment of essential tremor
}

\section{Leczenie drżenia samoistnego metoda głębokiej stymulacii wzgórza}

\author{
Tomasz Mandat ${ }^{1,2}$, Henryk Koziara ${ }^{1,2}$, Rafał Rola ${ }^{3,4}$, Wiesław Bonicki ${ }^{1,2}$, Paweł Nauman ${ }^{1,2}$ \\ 1Center of Oncology Maria Sklodowska-Curie Memorial Institute, Warsaw, Poland \\ 2Department of Neurosurgery, Institute of Psychiatry and Neurology, Warsaw, Poland

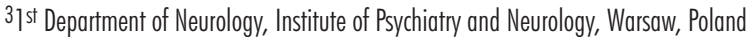 \\ ${ }^{4}$ Department of Physiology and Pathophysiology, Medical University of Warsaw, Warsaw, Poland
}

Neurologia i Neurochirurgia Polska 2011; 45, 1: 37-41

\begin{abstract}
Background and purpose: Quality of life can be severely impaired by essential tremor (ET) being the main cause of the patient's disability. The authors present a group of ET patients treated with deep brain stimulation of the ventral intermediate nucleus of the thalamus (Vim DBS). The aim of the study was to evaluate the efficacy and safety of Vim DBS in the treatment of ET.

Material and methods: Between 2006 and 2009, 8 female and 10 male ET patients were treated with Vim DBS. Mean age at implantation was $63 \pm 15$ years. ET lasted from 4 to 30 years (mean 12 years). Clinical condition of the group was evaluated before surgery and 3 months after implantation with spirography (spiral drawings), the modified Fahn (Tremor Rating Scale, TRS) scale, and the modified ADL (Activity of Daily Living) scale. The Vim was localized with CT and MRI. The procedures of implantation were performed under local and general anaesthesia. A bilateral procedure was performed in 11 cases and a unilateral procedure was performed in 7 cases.

Results: The therapeutic effect of DBS was maintained at the follow-up in the third month following surgery. Mean contralateral limb tremor reduction was $79 \%$. Head tremor reduction was reported by $75 \%$ of patients in the bilateral Vim DBS subgroup and $50 \%$ of patients in the unilateral Vim DBS subgroup. Mean ADL score improved by $61 \%$.
\end{abstract}

\section{Streszczenie}

Wstęp i cel pracy: Drżenie samoistne (DS) może w znaczący sposób obniżać jakość życia chorych, będąc niejednokrotnie przyczyną ich inwalidztwa. Autorzy przedstawiają grupę chorych na DS leczonych metoda głębokiej stymulacji jądra brzuszno-pośredniego wzgórza (nucleus ventralis intermedius thalami deep brain stimulation - Vim DBS). Celem pracy była ocena skuteczności i bezpieczeństwa leczenia DS metodą Vim DBS.

Materiał i metody: W latach 2006-2009 metoda Vim DBS leczono 8 kobiet i 10 mężczyzn chorych na DS. Średni wiek chorych w dniu operacji wynosił $63 \pm 15$ lat. Czas trwania choroby wahał się pomiędzy 4 a 30 lat (średnio 12 lat). Stan pacjentów oceniano przed zabiegiem chirurgicznym oraz 3 miesiące po zabiegu z wykorzystaniem spirografii (rysowania spirali), zmodyfikowanej skali Fahna (Tremor Rating Scale - TRS) oraz zmodyfikowanej skali ADL (Activity of Daily Living). W celu lokalizacji jądra brzuszno-pośredniego wzgórza wykonywano tomografię komputerową oraz rezonans magnetyczny. Zabiegi przeprowadzono w znieczuleniu miejscowym i ogólnym. U 11 pacjentów elektrody wszczepiono obustronnie, a u 7 pacjentów - jednostronnie.

Wyniki: Efekt terapeutyczny utrzymywał się po inicjacji stymulacji głębokiej w trzymiesięcznej obserwacji u wszystkich chorych. Stwierdzano zmniejszenie drżenia przeciwstronnej kończyny średnio o 79\%. Nasilenie drżenia głowy zmniejszyło się u $75 \%$ chorych leczonych stymulacją obustronną

Correspondence address: dr med. Tomasz Mandat, Centrum Onkologii - Instytut, Klinika Nowotworów Układu Nerwowego, ul. Roentgena 5 , 02-781 Warszawa, e-mail: tomaszmandat@yahoo.com Received: 27.04.2010; accepted: 12.10.2010 
Conclusions: Vim DBS is a safe and effective method of ET treatment. Vim DBS improves activities of daily living of ET patients.

Key words: essential tremor, deep brain stimulation, thalamus.

\section{Introduction}

Essential tremor (ET) is one of the most common movement disorders. The first symptoms of ET appear at the age of 35-45. The tremor progresses with age, frequently being the main cause of the patient's disability. Tremor among ET patients is most often located in the upper limbs; the head and tongue or even lower limbs are involved less frequently. More than half of ET patients might benefit from pharmacotherapy. The group of patients with severe tremor who do not benefit from or who do not tolerate pharmacotherapy might be qualified for surgery - thalamotomy or thalamic deep brain stimulation (ventral intermediate nucleus of thalamus deep brain stimulation, Vim DBS). The efficacy of thalamotomy and Vim DBS is comparable. Thalamotomy carries a higher complication rate than Vim DBS. The risk of irreversible complications after thalamotomy, especially if performed bilaterally, led to the acceptance of Vim DBS as the treatment of choice for the majority of ET patients [1-16]. Longer surgical procedure, the need for general anaesthesia and frequent visits for programming and reprogramming of Vim DBS, and the need for future internal pulse generator exchange, explains why thalamotomy is still used in selected ET cases. The definitive, consensual decision about the type of treatment should be made by the patient himself with the help of a movement disorders team. The authors present a group of patients treated with Vim DBS for ET. The aim of the study was to evaluate the efficacy and safety of Vim DBS in ET treatment.

\section{Material and methods}

Between 2006 and 2009, 8 female and 10 male ET patients were treated with Vim DBS. Mean age at implantation was $63 \pm 15$. ET lasted from 4 to 30 years (mean 12). The clinical condition of the group was evaluated with spirography (spiral drawings), the modified Fahn scale (Tremor Rating Scale, TRS), and the modi- oraz u 50\% chorych leczonych stymulacją jednostronną. Średnio poprawa w ADL wynosiła $61 \%$.

Wnioski: Głęboka stymulacja jądra brzuszno-pośredniego wzgórza jest metodą bezpieczną i skuteczną w leczeniu DS, mającą wpływ na sprawność wykonywania codziennych czynności u chorych z DS.

Słowa kluczowe: drżenie samoistne, głęboka stymulacja mózgu, wzgórze.

fied ADL (Activity of Daily Living) scale [17]. After neurological, psychological and neurosurgical qualification patients were admitted to the department of neurosurgery. ET was the main cause of subjects' disability in the studied group. Tremor lasted for at least 6 hours/day with intensity of 3-4 on the TRS. The exclusion criteria included: psychiatric disorders, previous thalamotomy on the side of the planned DBS, coagulopathy or immunodeficiency. The procedures were performed under local and general anaesthesia. After placement of the stereotactic frame, computed tomography (CT) scanning with contrast injection and merging of $\mathrm{CT}$ and magnetic resonance images were performed to identify the target point according to the indirect method $[6,18,19]$. Macrostimulation was conducted in the whole group. Microrecording with 1 to 3 microelectrodes was performed in 3 patients [20]. After identification of the surgical target, a permanent electrode was implanted under fluoroscopic guidance. After dismounting of the stereotactic frame, the system was connected with the internal pulse generator and internalized. Bilateral procedures were performed in 11 cases and unilateral (left-sided) procedures were performed in 7 cases. The stimulation was initialized on the first day following surgery.

\section{Results}

Intraoperative contralateral limb tremor reduction was reported in the whole group of patients during stimulation. The therapeutic effect of DBS was maintained at the follow-up on the first day and 3 months following surgery. Initial parameters of the monopolar stimulation were set at the frequency of $130 \mathrm{~Hz}$ with pulse width of $80 \mu$ s and mean amplitude up to $1.0 \mathrm{~V}$. The parameters were readjusted over time according to the clinical effect at the follow-up. If necessary, the stimulation was changed to bipolar and the amplitude was increased up to $2.5 \mathrm{~V}$.

Mean contralateral tremor reduction measured with the modified Fahn scale was 79\%. Three subjects reported $100 \%$ improvement in contralateral limb tremor 
(from 4 to 0 on the Fahn scale). Twelve subjects reported $80 \%$ improvement in limb tremor (4 points on the Fahn scale). Two subjects reported $60 \%$ improvement (3 points on the Fahn Scale) and 1 subject reported 20\% improvement (1 point on the Fahn scale). Head tremor was reduced at least by 1 point on the TRS in 75\% (6/8) of patients treated with bilateral Vim DBS and in 50\% (3/6) of those treated with unilateral Vim DBS. Reduction by 2 points on the TRS was reported in $25 \%$ of patients treated with bilateral Vim DBS (2/6). All studied subjects reported improvement of the functions evaluated by ADL. Mean improvement of ADL was 61\% (Table 1). Improvement measured with spirography was noted among the whole group.

Skin erosion over the cerebral electrode was reported in 1 case (1/29 implantations, 3\%). Intracerebral haemorrhage at the electrode path at the left frontal lobe was noted in 1 case (as observed in control CT) and clinically manifested in mild disorientation. Clinical symptoms of haemorrhage had disappeared in 1-week follow-up. Haemorrhage was not visible in the 1-month control CT scan.

\section{Discussion}

Essential tremor is one of the most common movement disorders. Prevalence of ET depends on the age of the evaluated group and varies from 0.01 to $20.5 \%$ with new diagnoses of 23.7 patients/year/100 thousand population up to over 600 in the population of patients aged over 65. The aetiology of ET is unknown. The quality of life of over $70 \%$ of ET patients is impaired by tremor, but only $10 \%$ of them receive any treatment $[1,5,18,19]$. Modern pharmacology allows tremor to be controlled among the majority of ET patients. Surgical treatment can be considered only if the conservative treatment is not tolerated or if there is no response to treatment. Appropriate ET diagnosis at the surgical qualification level is a key factor for successful treatment. Neurological qualification and acceptance by the patient of the offered type of treatment will impact future patient satisfaction and compliance in the follow-up $[1,3,5$, 21-23].

In the mid twentieth century, the first attempts of neurosurgical treatment of tremor were made. In those years extensive neurosurgical procedures were performed which reduced tremor only with excessive costs of patients' motor skills $[24,25]$. Thalamotomy, elaborated by Guiot in the 1960s, was a breakthrough in ET
Table 1. ADL Scale* used for evaluation of the efficacy of ET treatment with Vim DBS. Pre-surgical and post-surgical (3 months after implantation) state and improvement in each task are listed

\begin{tabular}{|rlccc|}
\hline No. & Task & $\begin{array}{c}\text { Before } \\
\text { surgery }\end{array}$ & $\begin{array}{c}\text { Three } \\
\text { months after } \\
\text { surgery }\end{array}$ & $\begin{array}{c}\text { Impro- } \\
\text { vement }\end{array}$ \\
\hline 1. & Feeding & 2.2 & 0.7 & $-70 \%$ \\
\hline 2. & Drinking & 2.6 & 0.7 & $-74 \%$ \\
\hline 3. & Pouring water & 2.2 & 0.7 & $-70 \%$ \\
\hline 4. & Brushing teeth & 1.6 & 0.4 & $-79 \%$ \\
\hline 5. & Face and hand hygiene & 1.1 & 0.3 & $-72 \%$ \\
\hline 6. & Taking bath or shower & 1.1 & 0.6 & $-50 \%$ \\
\hline 7. & Using toilet & 1.0 & 0.3 & $-69 \%$ \\
\hline 8. & Tying shoelaces & 1.8 & 0.8 & $-55 \%$ \\
\hline 9. & Fastening buttons & 1.9 & 0.6 & $-67 \%$ \\
\hline 10. & Handwriting & 2.5 & 1.5 & $-41 \%$ \\
\hline 11. & Book reading & 1.6 & 0.4 & $-72 \%$ \\
\hline 12. & Hand drawing & 2.2 & 1.2 & $-48 \%$ \\
\hline 13. & Phone dialling & 1.6 & 0.9 & $-43 \%$ \\
\hline 14. & Sending letters & 2.1 & 0.8 & $-61 \%$ \\
\hline 15. & $\begin{array}{l}\text { Locking door with } \\
\text { a key }\end{array}$ & 1.9 & 0.8 & $-57 \%$ \\
\hline & Results (0-45) & 27.5 & 10.2 & $-61 \%$ \\
\hline
\end{tabular}

*0 - able to perform independently, 1 - able to perform with effort and some help, 2 - able to perform with excessive effort, 3 -unable to perform independently

treatment, when efficacy and safety improved significantly $[6,19]$. Very good results of thalamotomy (tremor reduction up to $100 \%$ among ET patients) was followed by a relatively high complication rate, especially if thalamotomies were performed bilaterally. The introduction of Vim DBS in ET helped to reduce the complication rate and to maintain the high efficacy of treatment. Implantation of DBS is well tolerated but carries a risk related to the surgical procedure and adverse effects related to the stimulation itself. The surgical complication rate related to DBS implantation is estimated at $2-3 \%$. Neurological morbidity related to the procedure is estimated at $1 \%$ with mortality of $0.4 \%$. Adverse effects related to stimulation of the surrounding structures are usually not retained and are eliminated at the programming session [4-6,19,23-30].

Other, previously described anatomical targets such as the globus pallidus or other thalamic nuclei (VOP, VL) are not used nowadays because of the lower impact on tremor. Promising results in tremor reduction are 
reported with stimulation of the posterior subthalamic area, especially among patients with tremor and Parkinson disease $[31,32]$. It seems that the leading role of Vim as a surgical target for ET treatment will remain, because of its simplicity, high efficacy for tremor, and low complication rate $[6,11,19,31,32]$.

The efficacy of Vim DBS treatment in the group was evaluated with the modified Fahn scale, spirography and ADL. Tremor reduction was reported in the whole group and was most significant in feeding and personal hygiene abilities. Handwriting ability improved less significantly than the other evaluated activities. The minor improvement of handwriting might suggest that the most commonly used test for tremor evaluation spirography - is not sufficiently sensitive for evaluation of Vim DBS treatment. Additionally performed ADL evaluation might supplement post-surgical evaluation of Vim DBS tremor treatment.

The progressive character of ET is one of the reasons why the efficacy of thalamotomy and Vim DBS diminishes over the years. Application of cyclic stimulation with stimulation off over night might prolong the treatment efficacy. Reprogramming of the internal pulse generator, which is possible with DBS, gives the possibility of prolonging Vim DBS efficacy in long-term observation among ET patients as well [1,2,4,30].

\section{Conclusions}

1. Vim DBS is a safe and effective method of ET treatment.

2. Vim DBS improves activities of daily living of ET patients.

3. If no contraindications are present and this type of treatment is accepted by patient, Vim DBS should be identified as the treatment of choice for ET, especially if bilateral procedures are planned.

\section{Acknowledgement}

'Thalamic deep brain stimulation in the treatment of essential tremor' has been orally presented at the Scientific Conference of the Stereotactic and Functional Neurosurgery Section of the Polish Neurosurgical Association at Ustron, Poland on March 4-5, 2010.

\section{Disclosure}

Authors report no conflict of interest.

\section{References}

1. Berk C., Honey C.R. Bilateral thalamic deep brain stimulation for the treatment of head tremor. $J$ Neurosurg 2002; 96: 615-618.

2. Putzke J.D., Uitti R.J., Obwegeser A.A., et al. Bilateral thalamic deep brain stimulation: midline tremor. $J$ Neurol Neurosurg Psychiatry 2005; 76: 684-690.

3. Benabid A.L., Pollak P., Dongming G., et al. Chronic electrical stimulation of ventralis intermedius nucleus of the thalamus as a treatment of movement disorders. J Neurosurg 1996; 84: 203-214.

4. Schurman P.R., Bosch D.A., Bossuyt P., et al. A comparison of continuous thalamic stimulation and thalamotomy for suppression of severe tremor. $N$ Engl J Med 2000; 342: 461-468.

5. Schwalb J., Lozano A. Surgical management of tremor. Neurosurgery 2004; 14: 60-68.

6. Guiot G., Derome P., Trigo J.C. Le tremblement d'attitude. Indication la meilleure de la chirurgie stéreotaxique. Presse Med 1967; 75: 2513-2518.

7. Bain P.G., Findley L.J., Thompson P.D., et al. A study of hereditary essential tremor. Brain 1994; 117: 805-824.

8. Blond S., Caparros-Lefebvre D., Parker F., et al. Control of tremor and involuntary movement disorders by chronic stereotactic stimulation of the ventral intermediate thalamic nucleus. J Neurosurg 1992; 77: 62-68.

9. Findley L.J., Koller W.C. Essential tremor: a review. Neurology 1987; 37: 1194-1197.

10. Koller W., Pahwa R., Busenbark K., et al. High-frequency unilateral thalamic stimulation in the treatment of essential and parkinsonian tremor. Ann Neurol 1997; 42: 292-299.

11. Laitinen L. Stereotactic treatment of hereditary tremor. Acta Neurol Scand 1965; 41: 74-79.

12. Louis E.D. Essential tremor. N Engl J Med 2001; 345: 887-891.

13. Nagaseki Y., Shibazaki T., Hirai T., et al. Long-term followup results of selective VIM-thalamotomy. J Neurosurg 1986; 65: 296-302.

14. Louis E.D., Ferreira J.J. How common is the most common adult movement disorder? Update on the worldwide prevalence of essential tremor. Mov Disord 2010; 25: 534-541.

15. Sobstyl M., Ząbek M. Głęboka stymulacja jądra brzusznego pośredniego wzgórza w leczeniu drżenia samoistnego. Neurol Neurochir Pol 2007; 41: 160-168.

16. Sobstyl M., Ząbek M., Koziara H., et al. Stereotaktyczna brzuszno-boczna talamotomia w leczeniu drżenia samoistnego. Neurol Neurochir Pol 2006; 40: 179-185.

17. Fahn S., Tolosa E., Marin C. Clinical rating scale for tremor. In: Jankovic J., Tolosa E. [eds.]. Parkinson's disease and movement disorders. Urban \& Schwarzenberg, Baltimore 1988, pp. 225-234.

18. Guiot G., Arfel G. Derôme P. La chirurgie stéreotaxique des tremblements de repos et d'attitude. Gaz Med France 1968; 75 : 4029-4056.

19. Mercado R., Mandat T., Moore G.R., et al. Three-tesla magnetic resonance imaging of the ventrolateral thalamus: a correlative anatomical description. $J$ Neurosurg 2006; 105: 279-283.

20. El-Tahawy H., Lozano A.M., Dostrovsky J.O. Electrophysiological findings in Vim and Vc. In: Israël Z., Burchiel K.J. [eds.]. 
Microelectrode recording in movement disorders surgery. Thieme Medical Publisher, Inc., New York 2004.

21. Dogu O., Sevim S., Camdeviren H., et al. Prevalence of essential tremor: door-to-door neurological exams in Mersin Province, Turkey. Neurology 2003; 61: 1804-1807.

22. Deuschl G., Elble R.J. The pathophysiology of essential tremor Neurology 2000; 54 (Suppl 4), pp. S14-S20.

23. Benabid A.L., Pollak P., Gao D., et al. Chronic stimulation of the ventralis intermedius nucleus of the thalamus as a treatment of movement disorders. J Neurosurg 1996; 84: 203-214.

24. Cooper I.S. Ligation of the anterior choroidal artery for involuntary movements; parkinsonism. Psychiatr $Q$ 1953; 27: 317-319.

25. Cooper I.S. Heredofamilial tremor abolition by chemothalamectomy. Arch Neurol 1962; 7: 129-131.

26. Limousin P., Speelman J.D., Gielen F., et al. Multicentre European study of thalamic stimulation in parkinsonian and essential tremor. J Neurol Neurosurg Psychiatry 1999; 66: 289-296.

27. Hariz G.M., Lindberg M., Bergenheim A.T. Impact of thalamic deep brain stimulation on disability and health-related quality of life in patients with essential tremor. J Neurol Neurosurg Psychiatry 2002; 72: 47-52.

28. Ondo W., Jankovic J., Schwartz K., et al. Unilateral thalamic deep brain stimulation for refractory essential tremor and Parkinson's disease tremor. Neurology 1998; 51: 1063-1069.

29. Putzke J.D., Uitti R.J., Obwegeser A.A., et al. Bilateral thalamic deep brain stimulation: midline tremor control. $J$ Neurol Neurosurg Psychiatry 2005; 76: 684-690.

30. Sydow O., Thobois S., Alesch F., et al. Multicentre European study of thalamic stimulation in essential tremor: a six year follow up. J Neurol Neurosurg Psychiatry 2003; 74: 1387-1391.

31. Blomstedt P., Sandvik U., Tisch S. Deep brain stimulation in the posterior subthalamic area in the treatment of essential tremor. Mov Disord 2010; 25: 1350-1356.

32. Blomstedt P., Fytagoridis A., Tisch S. Deep brain stimulation of the posterior subthalamic area in the treatment of tremor. Acta Neurochir (Wien) 2009; 151: 31-36. 